\title{
Ruminal phosphorus availability from several feedstuffs measured by the nylon bag technique
}

\author{
David BRAVO ${ }^{\mathrm{a}, \mathrm{b} *}$, François MeschY ${ }^{\mathrm{b}}$, Catherine BogAERT ${ }^{\mathrm{a}}$, \\ Daniel SAUVANT $^{\mathrm{b}}$ \\ ${ }^{\text {a } U N C A A ~ E t s ~ U C A A B, ~ C h i e r r y ~ B P ~ 19, ~} 02402$ Château-Thierry Cedex, France \\ ${ }^{\mathrm{b}}$ Laboratoire de Nutrition et Alimentation, INRA, 16 rue Claude Bernard, \\ 75231 Paris Cedex 05, France
}

(Received 15 December 1999; accepted 1 March 2000)

\begin{abstract}
The present study was aimed at determining rumen phosphorus availability of some feedstuffs assessed with the nylon bag technique: forage (alfalfa), cereals (control-C wheat, formaldehyde treated-FT wheat, barley, corn), cereal by-products (wheat bran, wheat distillers, corn distillers) and meals (C and FT soya bean meals, rapeseed meals and sunflower meals). Rumen phosphorus availability was not uniform amongst the feedstuffs, varying from $33.1 \%$ (FT rapeseed meal) to $84.7 \%$ ( $\mathrm{C}$ wheat). Alfalfa phosphorus release kinetics showed high bacterial phosphorus contamination. Technological treatments affected phosphorus content of by-products by either increasing (wheat bran and distillers) or decreasing (corn distillers) after germ extraction from the seed. Formaldehyde treatment decreasing rumen phosphorus availability (from $77.2 \%$ vs. $89.4 \%$ for wheat to $33.1 \%$ vs. $64.4 \%$ for the rapeseed meal) may depreciate the phosphorus nutritional value of FT meals.
\end{abstract}

\section{availability / feedstuff / phosphorus / rumen}

Résumé - Disponibilité ruminale du phosphore de certaines matières premières mesurée à l'aide de la méthode des sachets nylon. Cet article décrit la détermination, par la méthode des sachets nylon, de la disponibilité ruminale du phosphore d'un fourrage (luzerne déshydratée), de céréales (blé, blé tanné, orge, maïs), de sous-produits de céréales (son et drêches de blé, drêches de maïs) et de tourteaux (soja et soja tanné, colza et colza tanné, tournesol et tournesol tanné). La disponibilité ruminale du phosphore est très variable : de 33,1\% (tourteau de colza tanné) à $84,7 \%$ (blé). La cinétique de libération du phosphore de la luzerne indique une importante contamination par le phosphore bactérien. Les traitements technologiques influencent la teneur en phosphore. L'extraction du germe enrichit (son et drêches de blé) ou appauvrit (drêche de maïs) en phosphore les sous-produits par rapport à la céréale. Le tannage au formol, diminuant la disponibilité ruminale du phosphore (de $77,2 \%$ vs. $89,4 \%$, blé à $33,1 \%$ vs. $64,4 \%$, tourteau de colza), semble pénaliser la valeur nutritionnelle du phosphore des tourteaux tannés.

disponibilité / matière première / phosphore / rumen

* Correspondence and reprints

E-mail: dbravo@ucaab.com 


\section{INTRODUCTION}

With the emergence of environmental concern, animal nutrition has to adapt to new constraints, particularly the control of animal production waste of nitrogen and phosphorus. Dietary phosphorus solubilisation has been studied in monogastric animals [11, 21, 27, 38], but only few authors have studied ruminants. Sixty percent of phosphorus waste of animal origin come from ruminants [34]. To decrease this waste, it is necessary to better understand phosphorus metabolism and particularly dietary phosphorus absorption determined by animal absorption capacity and dietary phosphorus availability. Today, the animal contribution to phosphorus absorption is taken into account in feeding recommendations $[1,10,22]$, however, dietary phosphorus availability is ignored despite its known influence on mineral utilisation [9]. Available phosphorus is the proportion of dietary phosphorus which is solubilised during digestion. Mineral requirements of rumen microbes are not negligible $[4,37]$. Therefore, rumen phosphorus availability could play an important role in dietary phosphorus quality. Previous authors have studied either phosphorus availability or phosphorus use by rumen microbes using radio labelled phosphorus [36], in vitro devices and in vivo trials [3, 37]. The aim of the present work was to measure the rumen phosphorus release from feedstuffs commonly used in ruminant diets by the nylon bag technique $[17,19]$ as previously done on forages $[5,6$, 26].

\section{MATERIALS AND METHODS}

\subsection{Animals, experimental diet}

The trial was carried out on three Holstein dry cows, fitted with rumen cannulas. Three weeks before and during the trial, each animal was fed $10 \mathrm{~kg}$ per day, twice a day at 8 am and $5 \mathrm{pm}$. The diet consisted of $70 \%$ hay and $30 \%$ concentrate $(43 \%$ barley, $40 \%$ beet pulp, $10 \%$ soya bean meal, $5 \%$ molasses and $2 \%$ of mineral and vita$\min \operatorname{mix}$ ).

\subsection{Nylon bags, experimental feedstuffs and procedure, chemical analyses}

Forage (dehydrated alfalfa), cereals (control-C wheat, formaldehyde treated-FT wheat, barley and corn grain), cereal byproducts (wheat bran, wheat distillers and corn distillers) and meals (C and FT soya bean, $\mathrm{C}$ and FT rapeseed and $\mathrm{C}$ and FT sunflower meals) were ground through a $0.8 \mathrm{~mm}$ screen [20]. Dry matter content was measured after $48 \mathrm{~h}$ at $80{ }^{\circ} \mathrm{C}$. The chemical compositions of the feedstuffs are included in Table I.

Two grams of the feedstuff were placed into the bags (pore size: $50 \mu \mathrm{m}$; internal dimensions: $5 \times 10 \mathrm{~cm}$ ) purchased from ANKOM $^{\circledR}$ (Fairport, NY 14450, USA). Each bag was duplicated. Two bags containing standard feed samples were systematically included in each set of bags (soya bean meal and dehydrated alfalfa), and were removed after respectively $4 \mathrm{~h}$ and $8 \mathrm{~h}$ rumen incubation time. For each feedstuff, 3 identical sets of bags (one per cow) were introduced in the rumen just before the morning feeding, and 2 bags were removed per cow at each incubation time, determined per feedstuff according to a preliminary dry matter degradation study. The bags were then quickly washed under cold water.

Dry matter (DM) content was determined after drying at $80{ }^{\circ} \mathrm{C}$ for $48 \mathrm{~h}$ on feedstuff samples and on the residues of each bag. For each feedstuff, the residues of the bags incubated the same time were pooled when the variation coefficient of dry matter degradability (DMD) was lower than 5\%. Otherwise, abnormal bags were removed [19]. 
Table I. Chemical composition of experimental feedstuffs.

\begin{tabular}{lccccc}
\hline & Dry matter content & Crude Protein & Crude Fiber $^{1}$ & Starch $^{1}$ & Phosphorus $^{1}$ \\
\hline Dehydrated alfalfa & 85.0 & 11.2 & 37.40 & nd & 0.25 \\
C wheat & 88.9 & 13.9 & 2.78 & 56.2 & 0.32 \\
FT wheat & 87.6 & 13.6 & 2.82 & 57.1 & 0.31 \\
Wheat distillers & 92.7 & 32.6 & 5.00 & 11.4 & 0.76 \\
Wheat bran & 88.3 & 15.0 & 7.90 & 24.7 & 0.88 \\
Corn & 89.4 & 8.6 & 1.66 & 64.9 & 0.30 \\
Corn distillers & 90.7 & 9.0 & 10.93 & 30.5 & 0.08 \\
Barley & 89.6 & 11.0 & 3.59 & 55.0 & 0.34 \\
C rapeseed meal & 90.1 & 33.3 & 12.25 & nd & 1.02 \\
FT rapeseed meal & 89.3 & 33.3 & 12.45 & nd & 1.02 \\
C sunflower meal & 91.2 & 27.5 & 25.10 & nd & 1.03 \\
FT sunflower meal & 90.6 & 27.5 & 26.50 & nd & 1.03 \\
C soya bean meal & 88.3 & 43.8 & 6.57 & nd & 0.63 \\
FT soya bean meal & 88.3 & 42.6 & 6.62 & nd & 0.64 \\
\hline
\end{tabular}

1: expressed in $\%$ of dry matter. C: control, FT: formaldehyde treated.

\subsection{Chemical analysis}

Crude protein $(\mathrm{CP}, \mathrm{N} \times 6.25)$, crude fibre (CF), starch and phosphorus were determined respectively after Kjedahl mineralisation (CEE directive, 93/28), using the Weende method (AFNOR, NF03-40), using the Ewers polarimetric method (CEE directive, 72/199) and the vanado-molybdate method (AFNOR, NF V18-106).

\subsection{Calculations}

Global dry matter degradability $\left(\mathrm{DMD}_{\mathrm{G}}\right)$ and global rumen phosphorus release $\left(\mathrm{RPR}_{\mathrm{G}}\right)$ were calculated according to a step by step method [20] assuming a rumen dilution rate of $6 \% \cdot \mathrm{h}^{-1}$. Kinetic values of dry matter degradability (DMD) and phosphorus release (RPR) were fitted to a non-linear model: $\mathrm{Y}=\mathrm{A}+\mathrm{B}\left(1-\mathrm{e}^{-\mathrm{ct}}\right)$ [23]. This model calculates three parameters A, B and C representing the rapidly degradable dry matter or rapidly releasable phosphorus fractions $\left(\mathrm{A}_{\mathrm{DM}}\right.$ or $\left.\mathrm{A}_{\mathrm{P}}\right)$, the degradable dry matter or releasable phosphorus fractions $\left(\mathrm{B}_{\mathrm{DM}}\right.$ or $\left.\mathrm{B}_{\mathrm{P}}\right)$ and the constant rate of dry matter degradation or phosphorus release for fraction $\mathrm{B}$ $\left(\mathrm{C}_{\mathrm{DM}}\right.$ or $\left.\mathrm{C}_{\mathrm{P}}\right)$.

The influence of the formaldehyde treatment was characterised by calculating for each incubation time, the difference of DMD and RPR between $\mathrm{C}$ and FT feedstuffs respectively called $\triangle \mathrm{DMD}(=\mathrm{DMD}$ for C feedstuff - DMD for FT feedstuff) and $\triangle \mathrm{RPR}$ (= RPR for C feedstuff - RPR for FT feedstuff). At a particular incubation time, and for C and FT feedstuffs the difference between DMD and RPR was also calculated $(\mathrm{DIFF}=\mathrm{DMD}-\mathrm{RPR})$.

\subsection{Statistical analyses}

Statistical analyses were performed using the SAS 6.12 software [33]. The constants of the Orskov and McDonald model [23] were fitted using a non-linear procedure. In all the models used, $\varepsilon$ was the residual error not explained by the model.

- The Pearson correlation coefficient $(\rho)$ between $D M D_{G}$ from our assay and $D M D_{G}$ 
from [2] was determined by a correlation procedure.

- The variance analysis was performed using the general linear model procedure. Four models were established (models 1 to 4), $Y_{i j}=\mu+F_{i j}+\varepsilon_{i j}$ where:

- $\mu$ is the mean of $Y$;

- $Y$ is $\mathrm{DMD}_{G i j}$ or $\mathrm{RPR}_{G i j}$ in model $1, A_{i j}$ or $\mathrm{B}_{\mathrm{ij}}$ or $C_{i j}$ for dry matter and phosphorus in model $2, \Delta \mathrm{DMD}_{i j}$ or $\Delta \mathrm{RPR}_{i j}$ in model 3 and DIFF (feedstuff) in model 4 ;

- $F$ is the effect of the 13 feedstuffs in model 1 , the $8 \mathrm{C}$ and FT feedstuffs in model 2 , the $4 \mathrm{C}$-FT feedstuffs in model 3 and the formaldehyde treatment ( 0 or 1$)$ in model 4.

- The Bonferroni test compared means with $p<0.05$ as the significance level and $p<0.1$ as the tendency level.

- Regressions were performed using the SAS regression procedure resulting in:

First order regression: $Y_{j}=\alpha+\beta \times \mathrm{x}+\varepsilon_{j}$ where:

- $Y$ is $A_{P}$ or $B_{P}$ or $C_{P}$;

- $\alpha, \beta$ are the regression coefficients;

- $\mathrm{x}$ is the chemical composition of the feedstuffs (CF, CP, starch, dry matter, phosphorus).

Polynomial regression: $\triangle D M D_{j}$ or $\triangle R P R_{j}=$ $\alpha+\beta \times t+\chi \times t^{2}+\delta \times t^{3}+\varepsilon_{j}$. where:

- $\alpha, \beta, \chi$ and $\delta$ are the regression coefficients;

- $t$ is the incubation time.

The equations were derivated to determine at which incubation time $\triangle D M D$ and $\triangle R P R$ were maximum (respectively $T_{R P R}$ max and TDMD max $_{\text {). }}$.

For all regression analysis, the results are given with residual mean square error $(\mathrm{s})$, square of the correlation coefficient $\left(\mathrm{r}^{2}\right)$ and significance level of the regression.

\section{RESULTS}

\subsection{Dry matter degradation}

The $\mathrm{DMD}_{\mathrm{G}}$ results are presented in Table II. Cereal dry matter was highly and
Table II. Dry matter degradability $\left(\mathrm{DMD}_{\mathrm{G}}\right)$ and rumen phosphorus release $\left(\mathrm{RPR}_{\mathrm{G}}\right)$ of the experimental feedstuffs (mean followed by standard deviation).

\begin{tabular}{lcc}
\hline & $D D_{G}(\%)$ & $R^{2 P R}(\%)$ \\
\hline Alfalfa & nd & nd \\
C wheat & $90.0(0.1)^{\mathrm{a}}$ & $89.4(0.2)^{\mathrm{a}}$ \\
FT wheat & $80.3(1.2)^{\mathrm{b}}$ & $77.2(1.4)^{\mathrm{d}}$ \\
C rapeseed meal & $60.4(2.3)^{\mathrm{de}}$ & $64.4(2.0)^{\mathrm{f}}$ \\
FT rapeseed meal & $38.7(1.3)^{\mathrm{h}}$ & $33.1(1.3)^{\mathrm{h}}$ \\
C soya bean meal & $79.2(1.1)^{\mathrm{b}}$ & $85.3(0.9)^{\mathrm{bc}}$ \\
FT soya bean meal & $56.2(0.9)^{\mathrm{ef}}$ & $71.8(1.1)^{\mathrm{e}}$ \\
C sunflower meal & $55.3(0.4)^{\mathrm{f}}$ & $70.1(0.5)^{\mathrm{e}}$ \\
FT Sunflower meal & $45.8(1.0)^{\mathrm{g}}$ & $45.6(0.7)^{\mathrm{g}}$ \\
Wheat distillers $^{\mathrm{g}}$ & $79.2(1.1)^{\mathrm{b}}$ & $85.1(0.7)^{\mathrm{c}}$ \\
Wheat bran & $70.5(0.9)^{\mathrm{c}}$ & $84.7(0.5)^{\mathrm{c}}$ \\
Barley & $87.7(0.8)^{\mathrm{a}}$ & $85.7(1.3)^{\mathrm{bc}}$ \\
Corn grain & $62.2(0.6)^{\mathrm{d}}$ & $88.8(0.4)^{\mathrm{ab}}$ \\
Corn distillers & $53.5(1.2)^{\mathrm{f}}$ & $66.4(1.0)^{\mathrm{f}}$
\end{tabular}

abcdefgh In a same column, means with different super scripts differ significantly $(p<0.05)$.

C: control, FT: formaldehyde treated. Rumen dilution rate: $6 \% \cdot \mathrm{h}^{-1}$.

rapidly degraded $(90.0 \% \pm 0.1$ for wheat and $87.7 \% \pm 0.8$ for barley) except for corn grain $(62.2 \% \pm 0.6)$. The $\mathrm{DMD}_{\mathrm{G}}$ of cereal by-products was low for corn distillers $(53.5 \% \pm 1.2)$ and high for wheat by-products, the wheat distillers being more degraded $(p<0.05)$ than wheat bran $(79.2 \%$ \pm 1.1 vs. $70.5 \% \pm 0.9)$. Rapeseed meal dry matter was less degraded $(p<0.05)$ than soya bean meal dry matter $(60.4 \% \pm 2.3 \mathrm{vs}$. $79.2 \% \pm 1.1)$. The less degraded dry matter feedstuffs were alfalfa $(52.7 \% \pm 2.7)$ and FT rapeseed meal $(38.7 \% \pm 1.3)$.

The parameters $\mathrm{A}_{\mathrm{DM}}, \mathrm{B}_{\mathrm{DM}}, \mathrm{C}_{\mathrm{DM}}$ for $\mathrm{C}$ and FT feedstuffs are presented in Table III. Dry matter fraction A decreased with formaldehyde treatment $(p<0.05)$ for wheat $(74.2 \% \pm 1.9$ vs. $11.0 \% \pm 0.6)$ and soya bean meal $(48.9 \% \pm 2.2$ vs. $29.6 \% \pm 0.6)$, or remained constant $(p>0.1)$ for rapeseed and sunflower meals. Dry matter fraction B increased $(p<0.05)$ for wheat $(21.5 \% \pm$ 1.4 vs. $77.2 \% \pm 0.8)$, tended to increase 
Table III. Parameters of dry matter degradation kinetics for $\mathrm{C}$ and FT feedstuffs: the rapidly $\left(\mathrm{A}_{\mathrm{DM}}\right)$ and slowly $\left(\mathrm{B}_{\mathrm{DM}}\right)$ degradable dry matter fractions, degradation rate $\left(\mathrm{C}_{\mathrm{DM}}\right)$ of the $\mathrm{B}_{\mathrm{DM}}$ fraction (mean followed by standard deviation for three animals).

\begin{tabular}{lrll}
\hline & $\mathrm{A}_{\mathrm{DM}}$ & $\mathrm{B}_{\mathrm{DM}}$ & $\mathrm{C}_{\mathrm{DM}}$ \\
\hline C wheat & $74.2(1.9)^{\mathrm{a}}$ & $21.5(1.4)^{\mathrm{e}}$ & $0.186(0.031)^{\mathrm{b}}$ \\
FT wheat & $11.0(0.6)^{\mathrm{d}}$ & $77.2(0.87)^{\mathrm{a}}$ & $0.495(0.044)^{\mathrm{a}}$ \\
C rapeseed meal & $13.05(3.7)^{\mathrm{d}}$ & $67.1(2.6)^{\mathrm{ab}}$ & $0.138(0.048)^{\mathrm{bc}}$ \\
FT rapeseel meal & $16.8(0.2)^{\mathrm{d}}$ & $72.0(3.9)^{\mathrm{ab}}$ & $0.022(0.004)^{\mathrm{d}}$ \\
C soya bean meal & $48.9(2.2)^{\mathrm{b}}$ & $57.0(7.7)^{\mathrm{bc}}$ & $0.078(0.029)^{\mathrm{dc}}$ \\
FT soya bean meal & $29.6(0.6)^{\mathrm{c}}$ & $68.3(11.0)^{\mathrm{ab}}$ & $0.025(0.008)^{\mathrm{d}}$ \\
C sunflower meal & $33.8(3.2)^{\mathrm{c}}$ & $34.7(2.2)^{\mathrm{de}}$ & $0.090(0.038)^{\mathrm{dc}}$ \\
FT sunflower meal & $27.8(2.3)^{\mathrm{c}}$ & $50.4(4.8)^{\mathrm{c}}$ & $0.032(0.005)^{\mathrm{d}}$ \\
\hline
\end{tabular}

abcde In a same column, means with different superscripts differ significantly $(p<0.05)$.

C: control, FT: formaldehyde treated.

$(p<0.1)$ for soya bean meal $(57.0 \% \pm 7.7$ vs. $68.3 \% \pm 11.0)$ and sunflower meal $(34.7 \% \pm 2.2$ vs. $50.4 \% \pm 4.8)$ and remained constant $(p>0.1)$ for rapeseed meal. However, the $\mathrm{C}_{\mathrm{DM}}$ degradation rate increased $(p<0.05)$ after formaldehyde treatment for wheat $(0.186 \% \pm 0.031$ vs. $0.495 \% \pm 0.044)$ whereas it decreased $(p<0.05)$ for rapeseed meal $(0.138 \pm 0.048$ vs. $0.022 \pm 0.004)$ and was constant $(p>0.1)$ for soya bean and sunflower meals.

\subsection{Phosphorus release}

Alfalfa phosphorus release kinetics (Fig. 1) presented successive increasing and decreasing phases. A decreasing phase was also observed for corn after $12 \mathrm{~h}$ of incubation (result not shown). Before $12 \mathrm{~h}$ incubation, corn phosphorus kinetics increased as for other feedstuffs (Figs. 1 and 2).

Cereal phosphorus was widely solubilised, $\mathrm{RPR}_{\mathrm{G}}$ reaching $89.4 \% \pm 0.2$ (wheat), $88.8 \% \pm 0.4$ (corn) and $85.7 \% \pm 1.3$ (barley). Wheat by-product phosphorus release was high $(85.1 \% \pm 0.7$ for distillers and $84.7 \% \pm 0.5$ for bran). Phosphorus was less released from corn distillers $(66.4 \% \pm 1.0$, $p<0.05)$ than from other cereals and byproducts (Tab. II).
$A_{P}, B_{P}, C_{P}$ for $C$ and $F T$ feedstuffs are presented in Table IV. $A_{P}$ decreased $(p<0.01)$ with formaldehyde treatment for soya bean meal $(61.3 \% \pm 1.8$ vs. $37.9 \% \pm$ $7.3)$ and sunflower meal $(30.3 \% \pm 0.8$ vs. $13.8 \% \pm 0.0$ ) whereas $\mathrm{B}_{\mathrm{P}}$ increased (soya bean meal, $47.1 \% \pm 6.9$ vs. $63.6 \pm 7.3$ and sunflower meal, $67.2 \% \pm 0.7$ vs. $90.2 \% \pm$ 1.1). Neither $A_{P}$ nor $B_{P}$ varied for rapeseed meal and wheat $(p>0.1)$. However, the $C_{P}$ release rate tended to decrease $(p<0.1)$ for rapeseed meal $(0.102 \pm 0.02$ vs. $0.020 \pm$ $0.001)$ or significantly decreased $(p<0.01)$ for wheat $(0.165 \pm 0.01$ vs. $0.064 \pm 0.002)$ and did not vary $(p>0.1)$ for sunflower and soya bean meals.

The $A_{P}$ decrease was associated with an increase in DM and CF contents of the feedstuffs:

$$
\begin{gathered}
\mathrm{A}_{\mathrm{P}}=2069( \pm 337)-22.9( \pm 3.7) \times \mathrm{DM} \\
\mathrm{s}=14.2, \mathrm{r}^{2}=0.62, p<0.001 \\
(\mathrm{DM}, \text { in percent })
\end{gathered}
$$

and

$$
\begin{gathered}
\mathrm{A}_{\mathrm{P}}=56.6( \pm 6.2)-1.98( \pm 0.4) \times \mathrm{CF} \\
\mathrm{s}=17.2, \mathrm{r}^{2}=0.45, p<0.001 \\
(\mathrm{CF} \text { in percent of } \mathrm{DM})
\end{gathered}
$$

$\mathrm{A}_{\mathrm{P}}$ was also highly related to $\mathrm{A}_{\mathrm{DM}}$

$$
\begin{gathered}
\mathrm{A}_{\mathrm{P}}=11.6( \pm 6.9)+0.7( \pm 0.1) \times \mathrm{A}_{\mathrm{DM}}, \\
\mathrm{s}=17.9, \mathrm{r}^{2}=0.40, p<0.001
\end{gathered}
$$




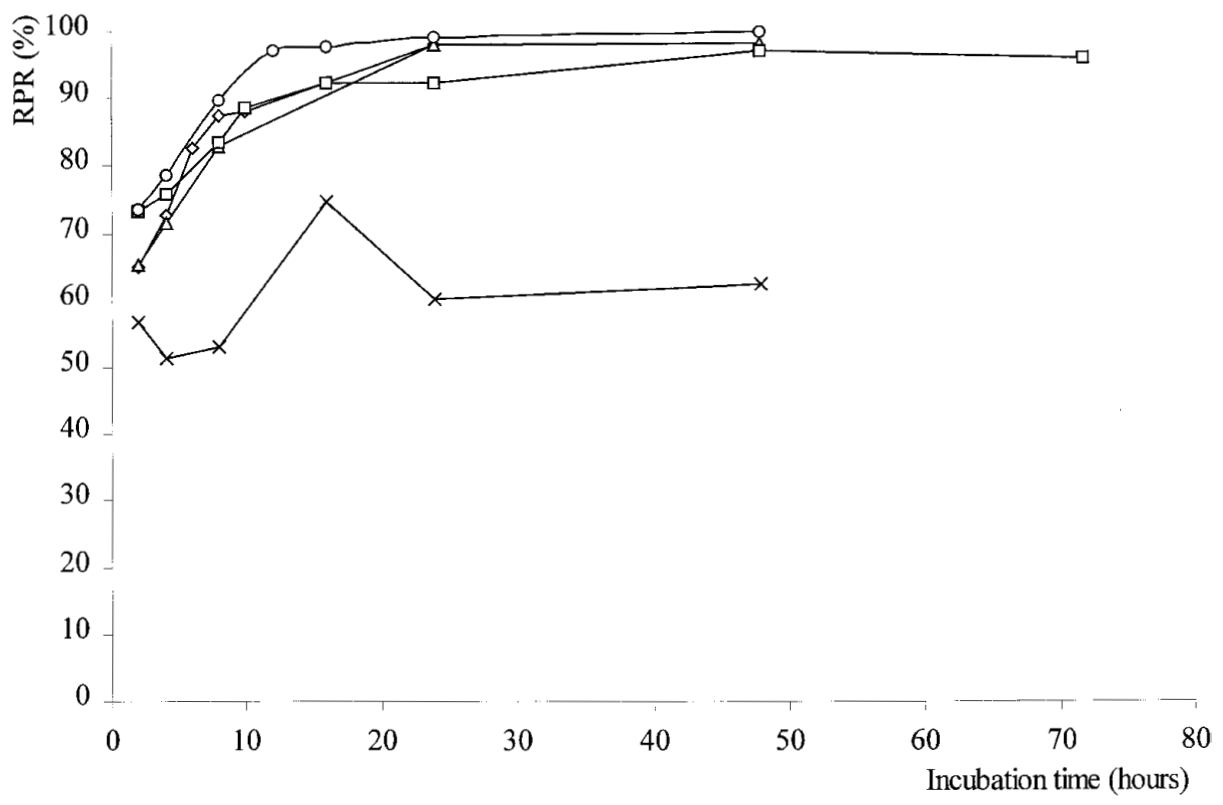

Figure 1. Rumen phosphorus release kinetics from wheat $(\bigcirc)$, barley $(\diamond)$, wheat distillers $(\square)$ wheat bran $(\triangle)$ and alfalfa $(\times)$.

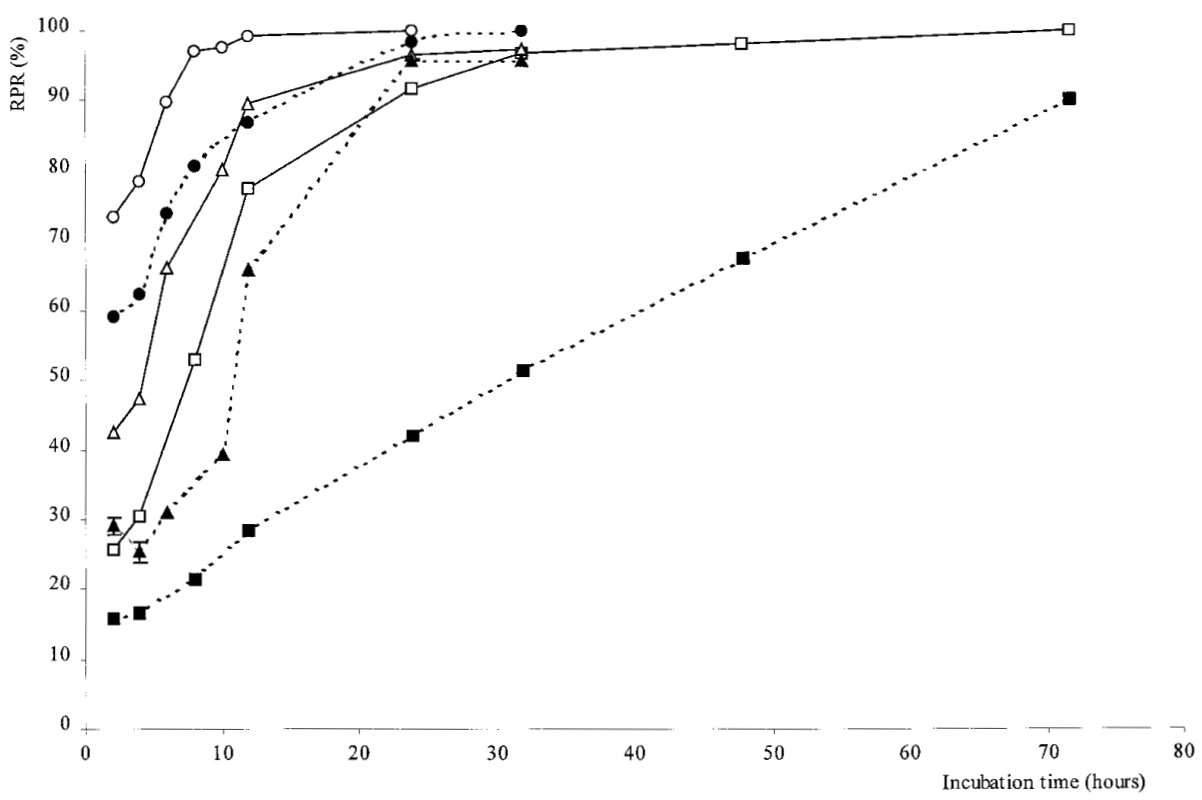

Figure 2. Rumen phosphorus release kinetics from $\mathrm{C}$ wheat $(\bigcirc$, solid line), FT wheat $(\boldsymbol{\bullet}$, dot line), $\mathrm{C}$ sunflower meal $(\triangle$, solid line), FT sunflower meal $(\boldsymbol{\Lambda}$, dot line) and $\mathrm{C}$ rapeseed meal ( $\square$, solid line), FT rapeseed meal $(\boldsymbol{\square}$, dot line). 
Table IV. Parameters of phosphorus release kinetics for C and FT feedstuffs: the soluble $\left(\mathrm{A}_{\mathrm{P}}\right)$ and releasable $\left(B_{P}\right)$ phosphorus fractions, release rate $\left(C_{P}\right)$ of the $B_{P}$ fraction (mean followed by standard deviation).

\begin{tabular}{lccc}
\hline & $\mathrm{A}_{\mathrm{P}}$ & $\mathrm{B}_{\mathrm{P}}$ & $\mathrm{C}_{\mathrm{P}}$ \\
\hline C wheat & $61.4(1.4)^{\mathrm{a}}$ & $38.9(1.3)^{\mathrm{c}}$ & $0.165(0.010)^{\mathrm{a}}$ \\
FT wheat & $53.6(2.2)^{\mathrm{a}}$ & $46.2(2.7)^{\mathrm{c}}$ & $0.064(0.002)^{\mathrm{b}}$ \\
C rapeseed meal & $3.4(2.8)^{\mathrm{d}}$ & $97.0(1.7)^{\mathrm{a}}$ & $0.102(0.020)^{\mathrm{ab}}$ \\
FT rapeseel meal & $8.0(2.5)^{\mathrm{cd}}$ & $94.2(2.1)^{\mathrm{a}}$ & $0.020(0.001)^{\mathrm{b}}$ \\
C soya bean meal & $61.3(1.8)^{\mathrm{a}}$ & $47.1(6.9)^{\mathrm{c}}$ & $0.073(0.031)^{\mathrm{b}}$ \\
FT soya bean meal & $37.9(7.3)^{\mathrm{b}}$ & $63.6(7.3)^{\mathrm{b}}$ & $0.103(0.072)^{\mathrm{ab}}$ \\
C sunflower meal & $30.3(0.8)^{\mathrm{b}}$ & $67.2(0.7)^{\mathrm{b}}$ & $0.086(0.005)^{\mathrm{ab}}$ \\
FT sunflower meal & $13.8(0.0)^{\mathrm{c}}$ & $90.2(1.1)^{\mathrm{a}}$ & $0.032(0.002)^{\mathrm{b}}$ \\
\hline
\end{tabular}

abcd In a same column, means with different superscripts differ significantly $(p<0.05)$.

C: control, FT: formaldehyde treated.

whereas $\mathrm{B}_{\mathrm{P}}$ was not correlated $(p>0.1)$ with $\mathrm{B}_{\mathrm{DM}}$. However, $\mathrm{B}_{\mathrm{P}}$ increased with $\mathrm{DM}$ and CF contents:

$$
\begin{gathered}
\mathrm{B}_{\mathrm{P}}=-2250( \pm 409)+26.0( \pm 4.6) \times \mathrm{DM}, \\
\mathrm{s}=17.3, \mathrm{r}^{2}=0.59, p<0.001
\end{gathered}
$$

and

$$
\begin{gathered}
\mathrm{B}_{\mathrm{P}}=39.9( \pm 7.6)+2.2( \pm 0.5) \times \mathrm{CF} \\
\mathrm{s}=20.7, \mathrm{r}^{2}=0.41, p<0.001
\end{gathered}
$$

The $C_{P}$ release rate was neither explained by DM fractions nor by the chemical composition of the feedstuffs $(p>0.1)$.

\subsection{Formaldehyde treatment effect}

Formaldehyde treatment systematically decreased $\mathrm{DMD}_{\mathrm{G}}$ and $R P R_{\mathrm{G}}$. As shown in Table V and VI, the highest effect was found for rapeseed $(\triangle \mathrm{DMD}=31.3 \%$ at $12 \mathrm{~h}$ and $\Delta \mathrm{RPR}=49.5 \%$ at $24 \mathrm{~h})$, sunflower $(\Delta \mathrm{DMD}$ $=15.3 \%$ at $8 \mathrm{~h}$ and $\triangle \mathrm{RPR}=40.6 \%$ at $16 \mathrm{~h}$ ) and soya bean meals $(\triangle \mathrm{DMD}=36.8 \%$ at $16 \mathrm{~h}$ and $\triangle \mathrm{RPR}=38.4 \%$ at $16 \mathrm{~h}$ ). Formaldehyde treatment induced a maximum effect on DMD and RPR at the TDMD ${ }_{\max }$ and $\mathrm{TRPR}_{\max }$ incubation times, calculated from the polynomial regression describing $\triangle \mathrm{DMD}$ and $\triangle \mathrm{RPR}$. TDMD $\mathrm{Dax}_{\max }$ was equivalent to $\mathrm{TRPR}_{\max }$ for soya bean $(17 \mathrm{~h})$ and rape- seed meals ( $22 \mathrm{~h}$ ). For sunflower meal, the maximum effect of treatment was earlier for DMD than for RPR (respectively $9 \mathrm{~h}$ and $16 \mathrm{~h}$ after the beginning of incubation).

The difference between dry matter degradation and phosphorus release $($ DIFF $=$ DMD-RPR) with incubation time revealed a different behaviour of FT and $\mathrm{C}$ feedstuffs. For FT feedstuffs, DIFF was systematically higher than for $\mathrm{C}$ feedstuffs as shown in Figure 3.

\section{DISCUSSION}

The $\mathrm{DMD}_{\mathrm{G}}$ values obtained in this work are highly correlated $(\rho=0.95)$ with previous works done in our laboratory [2]. The remaining difference was probably due to feedstuff variability in both works.

\subsection{Microbial contamination underestimates phosphorus availability}

The phosphorus content determined on the bag residue is the difference between phosphorus from the feedstuffs released in the rumen and rumen microbe phosphorus flowing into the bag. The relative 
Table V.1. Difference between C and FT feedstuff dry matter degradation ( $\triangle \mathrm{DMD}$, mean followed by standard deviation).

\begin{tabular}{lccccrrrr}
\hline$\Delta$ DMD & $2 \mathrm{~h}$ & $4 \mathrm{~h}$ & $8 \mathrm{~h}$ & $12 \mathrm{~h}$ & $16 \mathrm{~h}$ & $24 \mathrm{~h}$ & $48 \mathrm{~h}$ & $72 \mathrm{~h}$ \\
\hline Sunflower meal & $6.2(3.91)^{\mathrm{c}}$ & $10.1(3.3)^{\mathrm{c}}$ & $15.3(3.3)^{\mathrm{b}}$ & & $14.6(4.8)^{\mathrm{b}}$ & $7.6(2.9)^{\mathrm{b}}$ & $-3.3(1.7)^{\mathrm{b}}$ & $-2.5(1.6)^{\mathrm{c}}$ \\
Soya bean meal & $23.2(0.83)^{\mathrm{a}}$ & $28.0(1.1)^{\mathrm{a}}$ & $31.2(9.1)^{\mathrm{a}}$ & & $36.8(5.7)^{\mathrm{a}}$ & $33.8(6.7)^{\mathrm{a}}$ & $18.3(1.0)^{\mathrm{a}}$ & $26.2(6.3)^{\mathrm{a}}$ \\
Wheat & $13.9(2.7)^{\mathrm{b}}$ & $15.0(1.6)^{\mathrm{b}}$ & $14.3(1.6)^{\mathrm{b}}$ & $12.6(2.3)^{\mathrm{a}}$ & & $5.6(1.3)^{\mathrm{b}}$ & $0.2(1.3)^{\mathrm{b}}$ & $2.2(0.1)^{\mathrm{c}}$ \\
Rapeseed meal & $11.9(1.3)^{\mathrm{b}}$ & $16.1(1.7)^{\mathrm{b}}$ & $25.4(6.8)^{\mathrm{a}}$ & $31.3(4.5)^{\mathrm{b}}$ & & $29.0(4.0)^{\mathrm{a}}$ & $19.5(3.7)^{\mathrm{a}}$ & $14.7(0.7)^{\mathrm{b}}$ \\
\hline
\end{tabular}

abc In a same column, means with different superscripts differ significantly $(p<0.05)$. C: control, FT: formaldehyde treated.

$\Delta \mathrm{DMD}=\mathrm{DMD}$ of $\mathrm{C}$ feedstuff $-\mathrm{DMD}$ of FT feedstuff.

Table V.2. Regression of $\triangle \mathrm{DMD}$ on incubation time ( $\mathrm{t}$. The mathematical derivation of the equation gives the incubation time at which the DMD difference between FT and $\mathrm{C}$ feedstuffs (TDMD ${ }_{\max }$ ) was the highest. Equations are followed by the correlation coefficient $\left(\mathrm{r}^{2}\right)$, the model residual variance (s) and the level of significance of the model (p).

\begin{tabular}{lccccc}
\hline C-FT feedstuffs & \multicolumn{1}{c}{ Equation } & $\mathrm{r}^{2}$ & $\mathrm{~S}$ & $p$ & TDMD $_{\text {max }}$ \\
\hline Sunflower meal & $6.35+1.1 \times \mathrm{t}-4.9 \times 10^{-2} \times \mathrm{t}^{2}+4.4 \times 10^{-4} \times \mathrm{t}^{3}$ & 0.92 & 2.97 & 0.037 & 9.8 \\
Soya bean meal & $20.2+2.0 \times \mathrm{t}-7.4 \times 10^{-2} \times \mathrm{t}^{2}+6.7 \times 10^{-4} \times \mathrm{t}^{3}$ & 0.98 & 1.03 & 0.003 & 17.5 \\
Wheat & $15.8-0.272 \times \mathrm{t}-6.3 \times 10^{-3} \times \mathrm{t}^{2}+1.0 \times 10^{-4} \times \mathrm{t}^{3}$ & 0.97 & 1.44 & 0.007 & -1 \\
Rapeseed meal & $8.49+2.47 \times \mathrm{t}-7.5 \times 10^{-2} \times \mathrm{t}^{2}+5.8 \times 10^{-4} \times \mathrm{t}^{3}$ & 0.92 & 3.04 & 0.030 & 22.0 \\
\hline
\end{tabular}

${ }^{1}$ The corresponding equation has no maximum in the considered interval of time. C: control, FT: formaldehyde treated. 
Table VI.1. Difference between C and FT feedstuffs rumen phosphorus release ( $\Delta$ RPR, mean followed by standard deviation).

\begin{tabular}{|c|c|c|c|c|c|c|c|c|}
\hline$\Delta \mathrm{RPR}$ & $2 \mathrm{~h}$ & $4 \mathrm{~h}$ & $8 \mathrm{~h}$ & $12 \mathrm{~h}$ & $16 \mathrm{~h}$ & $24 \mathrm{~h}$ & $48 \mathrm{~h}$ & $72 \mathrm{~h}$ \\
\hline Sunflower meal & $13.51(4.07)^{\mathrm{b}}$ & $22.7(3.7)^{\mathrm{a}}$ & $35.0(2.7)^{\mathrm{a}}$ & & $40.6(3.7)^{\mathrm{a}}$ & $23.7(2.2)^{b}$ & $0.8(0.2 .)^{\mathrm{c}}$ & $1.6(0.2)^{\mathrm{c}}$ \\
\hline Soya bean meal & $20.62(0.62)^{\mathrm{a}}$ & $26.5(0.8)^{\mathrm{a}}$ & $29.3(7.0)^{\mathrm{a}}$ & & $38.4(3.6)^{\mathrm{a}}$ & $24.9(4.3)^{\mathrm{b}}$ & $19.1(1.1)^{b}$ & $27.2(0.6)^{\mathrm{a}}$ \\
\hline Wheat & $14.40(3.50)^{\mathrm{b}}$ & $16.0(2.1)^{b}$ & $15.7(1.7)^{b}$ & $16.3(2.5)^{\mathrm{a}}$ & & $12.3(1.8)^{\mathrm{c}}$ & $1.6(0.2)^{\mathrm{c}}$ & $0.02(0.03)^{\mathrm{c}}$ \\
\hline Rapeseed meal & $10.12(1.46)^{b}$ & $13.9(2.0)^{b}$ & $31.7(6.8)^{\mathrm{a}}$ & $48.9(2.6)^{\mathrm{b}}$ & & $49.5(2.6)^{\mathrm{a}}$ & $30.5(3.8)^{\mathrm{a}}$ & $12.0(0.3)^{b}$ \\
\hline
\end{tabular}

${ }_{\mathrm{abc}}$ In a same column, means with different superscripts differ significantly $(p<0.05)$. C: control, FT: formaldehyde treated.

$\triangle \mathrm{RPR}=\mathrm{RPR}$ of $\mathrm{C}$ feedstuff $-\mathrm{RPR}$ of FT feedstuff.

Table VI.2. Regression of DRPR on incubation time $(\mathrm{t})$. The mathematical derivation of the equation gives the incubation time at which the RPR difference between FT and C feedstuffs (TRPR ${ }_{\max }$ ) was the highest. The equations are followed by the correlation coefficient $\left(\mathrm{r}^{2}\right)$, the model residual variance (s) and the level of significance of the model (p).

\begin{tabular}{llcrrr}
\hline C-FT feedstuffs & Equation & $\mathrm{r}^{2}$ & $\mathrm{~S}$ & $\mathrm{p}$ & $\mathrm{TDMD}_{\max }$ \\
\hline Sunflower meal & $11.6+3.2 \times \mathrm{t}-0.125 \times \mathrm{t}^{2}+1.0 \times 10^{-3} \times \mathrm{t}^{3}$ & 0.90 & 6.8 & 0.051 & 16.8 \\
Soya bean meal & $19.7+1.6 \times \mathrm{t}-6.3 \times 10^{-2} \times \mathrm{t}^{2}+5.8 \times 10^{-4} \times \mathrm{t}^{3}$ & 0.46 & 3.3 & 0.543 & 17.4 \\
Wheat & $2.47+4.80 \times \mathrm{t}-0.13 \times \mathrm{t}^{2}+9.7 \times 10^{-4} \times \mathrm{t}^{3}$ & 0.96 & 5.7 & 0.027 & 9.2 \\
Rapeseed meal & $-0.58+5.17 \times \mathrm{t}-0.14 \times \mathrm{t}^{2}+1.0 \times 10^{-3} \times \mathrm{t}^{3}$ & 0.95 & 5.2 & 0.018 & 21.0 \\
\hline
\end{tabular}

C: control, FT: formaldehyde treated. 

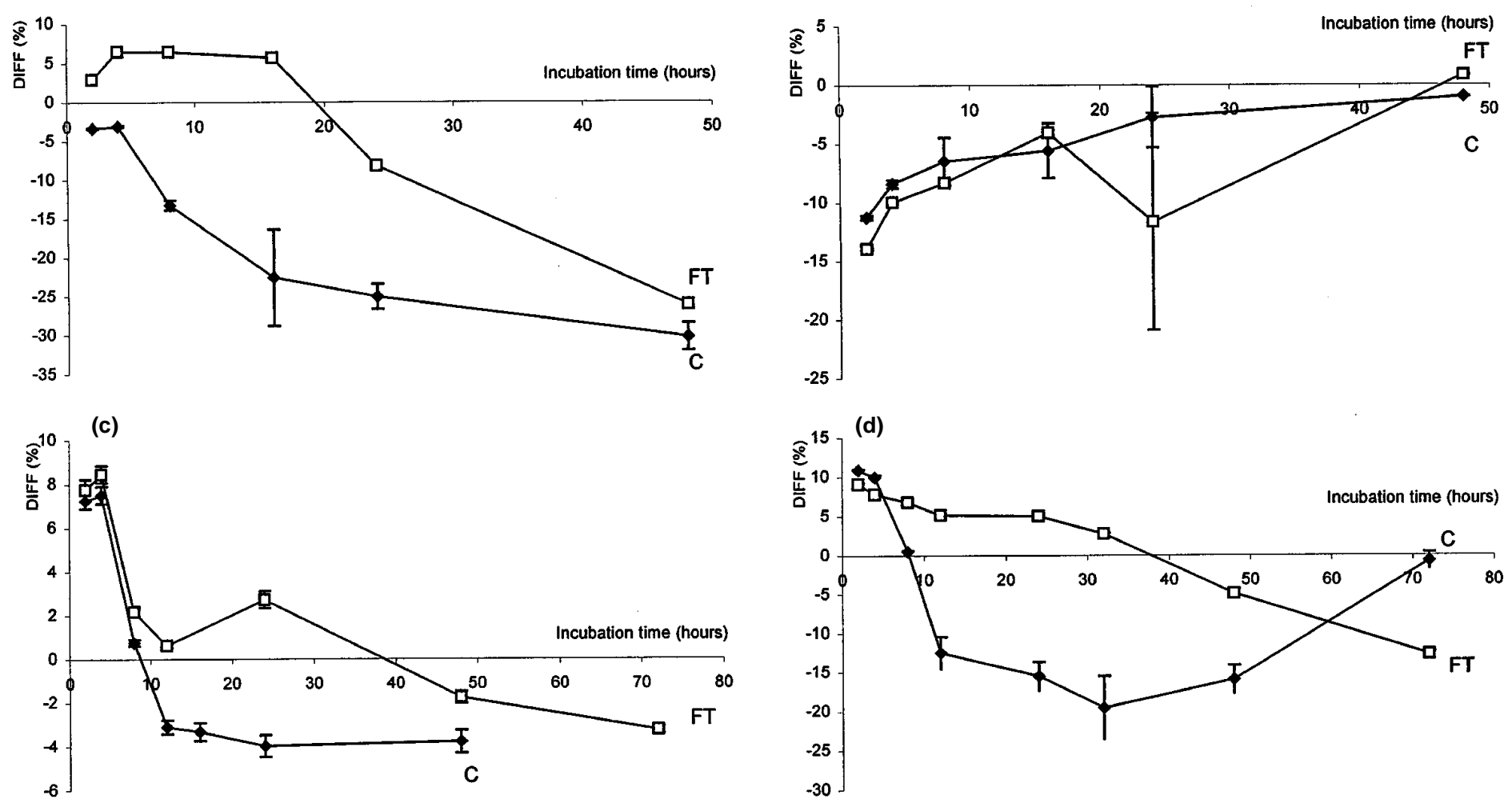

Figure 3. Difference between dry matter degradability and rumen phosphorus release kinetics (DIFF) for C $(\diamond)$ and FT ( $\square$ ) feedstuffs: (a) sunflower meal, (b) soya bean meal, (c) wheat, (d) rapeseed meal. (Mean of 6 bags, standard deviation.) 
importance of each flow will determine a bag phosphorus positive or negative enrichment and can lead to an under or over estimation of the feedstuff phosphorus release. Bacteria incompletely removed from incubation residues were already suspected [26] and checked [35, 39]. During studies on forage nitrogen degradation, contamination was measured [18, 39] and can represent up to $61 \%$ of the total nitrogen remaining in the bags after $12 \mathrm{~h}$ of incubation [18]. In mineral studies, bacterial contamination has been deduced but not quantified from rumen phosphorus release measurements on Italian rye-grass, wheat straw and alfalfa hay $[5,6]$. However, as for nitrogen [18], the extent of phosphorus contamination becomes quantitatively important for feedstuffs low in phosphorus such as forages [10] and with high microbial phosphorus content such as cellulolytic bacteria [12]. This would explain the successive increasing (higher phosphorus release) and decreasing (higher microbial contamination) shapes of the phosphorus release kinetics for alfalfa. Therefore, the nylon bag technique is not an accurate method for the measure of rumen phosphorus release from forages and feedstuffs with low phosphorus contents if used without a decontamination procedure as a stomacher apparatus [24].

\subsection{Technological treatments influence on phosphorus availability}

Our results show that technological treatments induce differences in rumen phosphorus release.

Phosphorus was quickly released for wheat distillers whereas it was slowly released from corn distillers. However, both by-products correspond to the peripheral parts of the cereal grain after removing the germ. In wheat, however, phosphorus is mainly concentrated in peripheral envelops under phytic form [28]. So removing the germ leads to a wheat by-product high in phytic phosphorus that is quickly released by the phytase activity of the rumen microbes $[30,31]$. On the contrary, when the germ is extracted from the corn grain, phosphorus is also extracted because corn phosphorus is concentrated in the germ [28]. Therefore, the low phosphorus content of this by-product is not easily released because it may be integrated as a structural part of the cell walls of the peripheral part of the grain and it may require previous dry matter degradation.

Formaldehyde treatment decreases rumen protein [40] and starch [20] degradability. Our results confirmed that rumen phosphorus release also decreases, mostly because of lower phytic phosphorus digestion [25]. Formaldehyde is assumed to disturb rumen enzyme action by reducing the accessibility of proteins or starch [40]. However, phosphorus links these molecules [8]. After formaldehyde treatment, phytic phosphorus may be confined and unavailable for phytase degradation. In this case, phosphorus release may require a previous dry matter degradation that would explain the increase of DIFF for FT sunflower (compared to $\mathrm{C}$ sunflower) at the beginning of the kinetics (dry matter is degraded quicker than phosphorus is released).

Heat treatments have also been shown to depress phytic phosphorus degradation in the rumen [15]. The technological treatments commonly used in the ruminant feed industry induce differences in phosphorus digestion leading to a flow of "rumen by pass" phytic phosphorus. More research is necessary to evaluate the further solubilisation of the remaining phytic phosphorus and the availability of phosphorus from FT feedstuffs for the ruminant.

\subsection{Phosphorus supply to rumen microbes}

Phosphorus released in the rumen is also used by microbes. When the rumen is phosphorus depleted, cellulolytic activity rapidly decreases [4, 13, 14], decreasing both diet 
utilisation and animal production [7]. The phosphorus requirement of rumen microbes is greater than that of the host animal [29] and was determined at $3.8 \mathrm{~g}$ of phosphorus per $\mathrm{kg}$ of digestible organic matter [12]. Phosphorus is mainly provided by saliva, but salivary phosphorus can be low as when high concentrate diets are fed [32], or before the start of chewing. Therefore, microbial requirements not satisfied by the salivary supply should be achieved through dietary phosphorus that may be much lower when FT meals are fed. Optimisation of both rumen digestion and phosphorus supply should integrate rumen requirements $[16$, 37] through a new variable of diet optimisation: rumen phosphorus availability. For instance, in spite of a high phosphorus content, FT rapeseed meal phosphorus would be depreciated because of its very low rumen phosphorus release.

Determining the true availability of dietary phosphorus for rumen microbes should involve the use of radioisotopes [36] or in vitro devices [3] whereas the RPR measured in our study is not an exact "phosphorus availability" measurement because unavailable phytic phosphorus can be released from the nylon bag. However, this approach reveals specific aspects of phosphorus digestion and could represent an interesting method for large scale feedstuff screening.

\section{CONCLUSION}

In this work, we showed that phosphorus release in the rumen is highly different for feedstuff like cereals and meals for instance. The rumen phosphorus release of concentrates rich in phosphorus can be determined by the nylon bag technique. For forages, a decontamination procedure should be added. Phosphorus requirements of rumen microbes are important because depletions rapidly decrease diet utilisation and animal production. In order to fit requirements and to decrease pollution, phosphorus should be supplied to the microbes with higher accuracy in terms of quantity and quality.

Our work shows that the knowledge of the dietary total phosphorus supply may be completed with information on phosphorus quality. In high concentrate diets, the possibility of phosphorus rumen deficiency should be investigated when formaldehyde treated meals are fed.

Rumen phosphorus release measured by the nylon bag technique is an interesting way to describe phosphorus quality of feedstuffs in current ruminant diets even if it is not exactly "phosphorus availability in the rumen". It may lead to a better knowledge of phosphorus utilisation by the ruminant and decrease wastes and pollution.

\section{ACKNOWLEDGEMENTS}

This work was partly supported by an ANRT grant (accorded by French Minister of Education and Research). The authors thank Hugues Brossier and the ruminant department, Christian Leroux, Jacques Roussel and the UCAAB laboratory for their collaboration.

\section{REFERENCES}

[1] AFRC, Technical committee on responses to nutrients, Report 6. A reappraisal of the calcium and phosphorus requirements of sheep and cattle, Nutr. Abstr. Rev. (series B) 61 (1991) 573-612.

[2] Chapoutot P., Étude de la dégradation in situ des constituants pariétaux des aliments pour ruminants, thèse, Institut National Agronomique Paris Grignon, 1999, 194 pp.

[3] Durand M., Foret R., Dumay C., Guéguen L., Utilisation du phosphate monoammonique chez le mouton. II.- Influence sur le métabolisme azoté de la microflore du rumen, Ann. Zootech. 25 (1976) 119-134.

[4] Durand M., Stevani J., Komisarczuk S., Effect of some major minerals on rumen microbial metabolism in a semi-continuous fermentor (Rusitec), Med. Fac. Landbouww Rijksuniv Gent 52 (1987) 1655-1663.

[5] Flachowsky G., Grün M., Influence of type of diet and incubation time on major elements release in sacco from Italian riegrass, untreated and ammonia treated wheat straw, Anim. Feed Sci. Technol. 36 (1992) 239-254. 
[6] Flachowsky G., Grün M., Polzin S., Kronemann $\mathrm{H}$., In sacco dry matter degradability and $\mathrm{Ca}$ $\mathrm{Mg}$ and $\mathrm{P}$ disappearance from italian ryegrass, alfalfa hay and wheat straw in sheep and goats, J. Anim. Physiol. Anim. Nutr. 71 (1994) 57-64.

[7] Georgievskii V.I., The physiological role of macroelements, in: Georgievskii V.I., Annenkov B.N., Samokhin V.I. (Eds.), Mineral nutrition of animals, Butterworths, London, Boston, Sydney, Durban, Wellington, Toronto 9, 1981, pp. $1-170$.

[8] Gifford S.R., Clydesdale F.M., Interactions among calcium zinc and phytate with three protein sources, J. Food Sci. 55 (1990) 1720-1724.

[9] Guéguen L., L'utilisation digestive réelle du phosphore du foin de luzerne pour le mouton mesurée à l'aide de ${ }^{32} \mathrm{P}$, Ann. Biol. Anim. Biochim. Biophys. 2 (1962) 143-149.

[10] INRA, Alimentation des bovins, ovins et caprins, Jarrige R. (Ed.), INRA Paris, 1988, 471 pp.

[11] Jongbloed A.W., Mroz Z., Kemme P., The effect of supplementary Aspergillus niger phytase in diets for pigs on concentration and apparent digestibility of dry matter, total phosphorus, and phytic acid in different sections of the alimentary tract, J. Anim. Sci. 70 (1992) 1159-1168.

[12] Komisarczuk S., Étude de l'influence du phosphore sur l'activité fermentaire, la protéosynthèse et les teneurs en ATP de contenus de rumen dans différents systèmes de culture continus, thèse, Université de Paris Sud, Centre d'Orsay, 1985, 200 pp.

[13] Komisarczuk-Bony S., Durand M., Effects of minerals on microbial metabolism, in: Jouany J.P. (Ed.), Rumen microbial metabolism and ruminant digestion, INRA, Paris, 1991, pp. 179-198.

[14] Komisarczuk S., Durand M., Dumay C., Morel M.T., Use of a semi-continuous culture system (Rusitec) to study the effects of phosphorus deficiency on rumen microbial digestion, Biol Anaer. Bact. (1986) 47-53.

[15] Konishi C., Matsui T., Park W., Yano H., Yano F., Heat treatment of soyabean meal and rapeseed meal suppresses rumen degradation of phytate phosphorus in sheep, Anim. Feed Sci. Technol. 80 (1999) 115-122.

[16] Lofgreen G.P., Kleiber M., The availability of the phosphorus in alfalfa hay, J. Anim. Sci. 12 (1953) 366-371.

[17] Mehrez A.Z., Orskov E.R., A study of the artificial fiber bag technique for determining the digestibility of feeds in the rumen, J. Agric. Sci. Camb. 88 (1977) 645-650.

[18] Michalet-Doreau B., Ould Bah M.Y., Estimation of the extent of bacterial contamination in bag residues and its influence on in sacco measurements of forage nitrogen degradation in rumen, XVIth. Intern. Grassl. Congr., Nice, 1989, pp. 909-910.
[19] Michalet-Doreau B., Vérité R., Chapoutot P., Méthodologie de mesure de la dégradabilité in sacco de l'azote des aliments dans le rumen, Bull. Tech. CRZV Theix, INRA 69 (1987) 5-7.

[20] Michalet-Doreau B., Philippeau C., Doreau M., In situ and in vitro ruminal starch degradation of untreated and formaldehyde-treated wheat and maize, Reprod. Nutr. Dev. 37 (1997) 305-312.

[21] Näsi J.M., Helander E.H., Partanen K.H., Availability for growing pigs of minerals and protein of a high phytate barley-rapeseed meal diet treated with Aspergillus niger phytase or soaked with whey, Anim. Feed Sci. Technol. 56 (1995) 83-98.

[22] NRC, Nutrient requirements of dairy cattle, Washington, National Academy Press, 1989.

[23] Orskov E.R., Mac Donald I, The estimation of protein degradability in the rumen from incubation measurements weighted according to rate of passage, J. Agric. Sci. Camb. 92 (1979) 499-503.

[24] Ould-Bah M.Y., Michalet-Doreau B., Jamot J., Colonisation bactérienne des résidus alimentaires des sachets incubés dans le rumen : utilisation du «stomacher » pour la réduire et conséquence sur la mesure de la dégradabillité ruminale de l'azote, Reprod. Nutr. Dév. 28 (1988) 107-108.

[25] Park W.Y., Matsui T., Konishi C., Kim S.W Yano F., Yano, H., Formaldehyde treatment suppresses ruminal degradation of phytate in soyabean meal and rapeseed meal, Br. J. Nutr. 81 (1999) 467-471.

[26] Playne J.M., Echevarri G., Megarrity R.G., Release of nitrogen, sulfur, phosphorus, calcium, magnesium, potassium and sodium from four tropical hays during their digestion in nylon bags in the rumen, J. Sci. Food Agric. 59 (1978) 520-526.

[27] Pointillart A., Enhancement of phosphorus utilisation in growing pigs fed phytate rich diets using rice bran, J. Anim. Sci. 69 (1991) $1109-1115$.

[28] Pointillart A., Phytates, phytases : leur importance dans l'alimentation des monogastriques, INRA Prod. Anim. 7 (1994) 29-39.

[29] Preston R.L., Pfander W.H., Phosphorus metabolism in lambs fed varying phosphorus intake, J. Nutr. 83 (1964) 369-378.

[30] Raun A., Cheng E., Burroughs W., Phytate phosphorus hydrolysis and availability to rumen microorganisms, J. Agric. Food Chem. 10 (1956) 867-871.

[31] Reid R.L., Franklin M.C., The utilisation of phytate phosphorus by sheep, Aust. Vet. J. (1947) 136-140.

[32] Scott D., Buchan W., The effects of feeding either roughage or concentrate diets on salivary phosphorus secretion, net intestinal phosphorus absorption and urinary phosphorus in the sheep, Q. J. Exp. Physiol. 70 (1985) 365-375. 
[33] SAS Institute, SAS User's Guide: Statistics SAS Institute INC., Cary, NC, 1990.

[34] Tamminga S., Nutrition management of dairy cows as a contribution to pollution control, J. Dairy Sci. 75 (1992) 345-357.

[35] Varvikko T., Lindberg J.E., Estimation of microbial nitrogen in nylon bag residues by feed ${ }^{15} \mathrm{~N}$ dilution, Br. J. Nutr. 54 (1985) 473-481.

[36] Vitti D.M.S.S., Silva Filho J.C., Abdalla A.L., Phosphorus availability for rumen microorganisms: effect of different sources, J. Nuclear Agric. Biol. 17 (1988) 186-187.
[37] Witt K.E., Owens F.N., Phosphorus: ruminal availability and effects on digestion, J. Anim. Sci. 56 (1983) 930-937.

[38] Young L.G., Leunissen M., Atkinson J.L., Addition of microbial phytase to diets of young pigs, J. Anim. Sci. 71 (1993) 2147-2150.

[39] Zander R., Flachowsky G., Gruhn K., The rumen ${ }^{15} \mathrm{~N}$ degradation in sacco and the in vivo digestibility of ${ }^{15} \mathrm{~N}$ from straw in wether and pony, Arch. Tierernaehr. 39 (1989) 361-368.

[40] Zelter S.Z., Leroy F., Tissier J.P., Protection des protéines alimentaires contre la désamination bactérienne dans le rumen, Ann. Biol. Anim. Biochim. Biophys. 10 (1970) 111-122. 